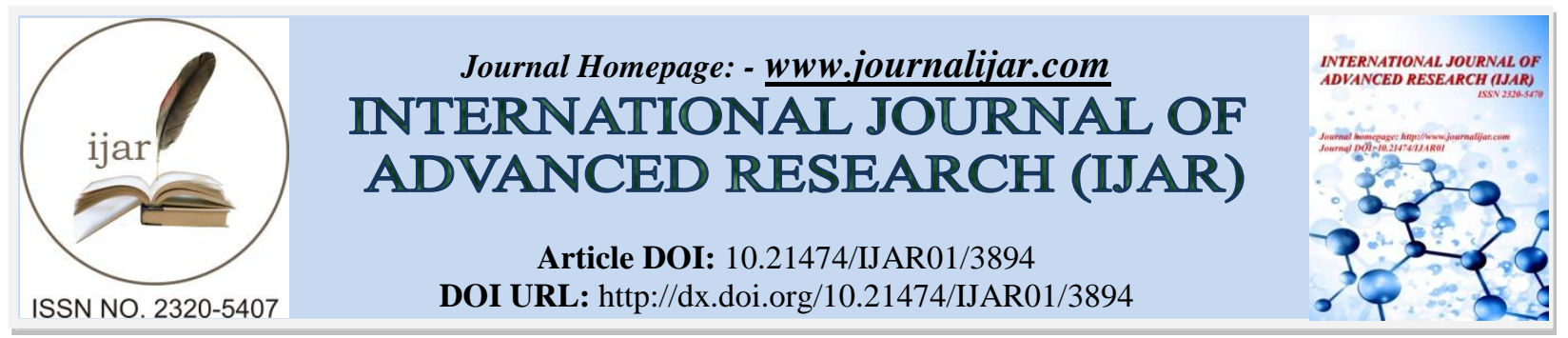

RESEARCH ARTICLE

\title{
CHEMICAL COMPOSITION AND ANTIBACTERIAL ACTIVITY OF PAJANELIA LONGIFOLIA (WILLD.) K.SCHUM AGAINST MULTI DRUG RESISTANT CLINICAL ISOLATES FROM DIABETIC FOOT ULCER.
}

\author{
Katherin Steffy, G. Shanthi and V. Natarajan. \\ Division of Microbiology, Rajah Muthiah Medical College, Annamalai University, Tamilnadu, India.
}

\section{Manuscript Info \\ Manuscript History \\ Received: 01 February 2017 \\ Final Accepted: 15 March 2017 \\ Published: April 2017}

Key words:-

DFU, Antibiotic Resistance,

Pajanelia Longifolia, GC-MS analysis

Antibacterial activity

\begin{abstract}
Antibiotic drug resistance has lead to the need for alternate treatment strategies and recently paid attention to extracts and biologically active compounds isolated from plant species. The present study performed phytochemical screening and GC-MS analysis to identify the possible presence of various phytochemical constituents present in the Petroleum ether, Ethyl acetate, Ethanol and Aqueous leaf extracts of P. longifolia. The antibacterial activity was evaluated by disc diffusion and MIC/MBC assays against Multi drug resistant bacterial isolates from DFU and ATCC bacterial strains. The phytochemical screening of leaves extracts proved the occurrence of diverse phytochemicals and GC-MS analysis identified presence of major compounds Phytols (36.37-52.17\%), Flavones (13.50\%), Esters (9.18-20.01\%), Carboxylic acids $(4.76 \%)$. Ethyl acetate, ethanol extracts of the plant showed potential antibacterial activity against P. aeruginosa ATCC 27853, S. aureus ATCC 29213, MDR- MRSA, MDR- P. aeruginosa, MDR- E. coli, MDR- A. baumanii. From this study, it can be concluded that leaves of and Pajanelia longifolia (Willd.) K Schuman has potential antibacterial compounds that may be used for developing new drugs against multiple drug resistant pathogenic bacteria.
\end{abstract}

Copy Right, IJAR, 2017,. All rights reserved.

\section{Introduction:-}

Diabetic foot ulcer (DFU) is one of major complications of diabetes mellitus (DM). Patients with chronic diabetes develop foot syndrome mainly due to triad of factors such as neuropathy, vascular changes and infections (Alavi et al., 2014). Majority of Diabetic foot ulcers turns out to be highly infected with microorganisms, leading to increased hospitalization, probable lower extremity amputations and increased mortality (Rogers et al., 2011). Bacterial etiology of DFU are polymicrobial in nature, encompassing both aerobic and anaerobic bacteria (Sapico et al., 1980; Sussman et al., 1992; Caballero et al., 1998; Abdulrazak et al., 2005; Charles et al., 2015).

Alarming increase in antibiotic resistance against bacterial isolates from diabetic foot ulcer has also been reported (Goldstein et al., 1996; Cunha et al., 2000; Mendes et al., 2012). Most of the drug resistant bacteria are also capable of producing biofilms and act synergistically with poly microbes present within the wound to form biofilm communities (Murali et al., 2014). Increased prevalence of Multi drug resistance (MDR) organisms including Methicillin Resistant Staphylococcus aureus (MRSA) strains (Djahmi et al., 2013), Extended Spectrum $\beta$ lactamases (ESBL) (Gadepalli et al., 2006) and NDM-1 (New Delhi metallo $\beta$-lactamase producing gram negative 
bacilli) (Srivastava et al., 2011) and even MDR Mycobacterium tuberculosis have been isolated from DFUs (Baveja et al., 2010). Therefore it is crucial to come up with an alternate treatment strategy, in this crisis situation of antibiotic drug resistance.

In India, various traditional health care systems such as Ayurveda, Siddha, Unani etc solely depends on the plants and their products for the recovery of various ailments. Medicinal plants used traditionally found to contain several phytochemical compounds that aid in recovery of infections (Patwardhan et al., 2004). Thus drugs developed from the traditionally used medicinal plants, could provide higher routes to the invention, development and delivery of latest medication with increased performance in terms of value, safety and effectiveness (Kong et al., 2009). In order to elucidate the various properties of medicinal plants systematic research has to be done, so that the plant resources won't be destroyed due to improper use.

Plants which belongs to family Bignoniaceae are said to have significant medicinal values such as antioxidant activity, antiviral activity (Kernan et al., 1998), antiplasmodial activity (Onegi et al., 2002), anti-diarroheal activity (Longanga Otshudi et al., 2000), anti-microbial activity (Akunyili et al., 1991). Pajnelia Longifolia (Wild) Schum of family Bignoniaceae is an evergreen deciduous trees widely distributed in India, Srilanka, Thailand, North Sumatra, Natuna islands and Myanmar (Roy Choudhury et al., 2015). In India Pajnelia longifolia have been distributed in Western Peninsular India, North East India and Nicobar islands (Chander et al., 2015). Traditional healers in the tribal communities of Tripura have been using bark of Pajnelia longifolia for the treatment of Jaundice (Kumar Anil., 2007). Tribal communities of Assam have been using leaves of Pajnelia longifolia for the treating skin and nail infections (Chin et al., 2007). Ethnomedical practioners of Dakshina kannada district of Karnataka state uses pajnelia leaves for treating eczema (Padayana, 2011). Thus the aim of the present study is to identify various secondary metabolites present in petroleum ether, ethyl acetate, ethanol and aqueous extract of Pajnelia longifolia leaf through phytochemical and GC-MS analysis and evaluation of its antibacterial potential against standard bacterial strains and antibiotic resistant bacterial isolates from Diabetic Foot Ulcer.

\section{Materials \& Methods:- \\ Ethics:-}

The research was approved by the Institutional Human Ethical Commitee of Annamalai University (Ref No:M18/RMMC/2015) for the collection of the pus sample to determine the bacteriological profile and antibiotic susceptibility pattern from Diabetic Foot Ulcer patients admitted to Rajah Muthiah Medical College, Annamalai University.

\section{Collection of Plant material:-}

Plant leaves were collected from the forest areas of Western Ghats, South India from the month of June 2016. The plants were identified and authenticated by Kerala Forest Research Department (KFRI/SILVA/GEN16). The plant material was thoroughly washed with clean water allowed to shade dry. The dried leaves were pulverized to coarse powder and kept in an airtight container.

\section{Preparation of Plant extract:-}

Dried pulverized plant material was successively extracted with series of selected solvents from high to low polarity such as Petroleum ether, Ethyl acetate, Ethanol and Aqueous. 350gm of plant material was exhaustively extracted with 2 liters of respective solvents successively for twelve hours in a soxhlet apparatus. At the end of each extraction, the plant material was dried and then repacked for the next course of extraction. The crude extract obtained at every step was filtered with whatmann No.1 filter paper, was concentrated using rotary evaporator under reduced pressure and stored at $4^{0} \mathrm{C}$.

\section{Preliminary phytochemical screening:-}

All the extracts were analyzed for preliminary phytochemical qualitative screening to identify the presence of various secondary metabolites as per methods given by Harborne. (1998).

\section{Gas Chromatography-Mass Spectroscopy (GC-MS) Analysis:-}

$2 \mu \mathrm{l}$ of the ethanol, ethyl acetate extract of leaves of Pajnelia longifolia was employed for GC-MS analysis. These extracts were dissolved in HPLC grade methanol and subjected to JEOL GCMATE II GC-MS. The column (HP5) was amalgamated with silica $50 \mathrm{~m} \mathrm{x} 0.25 \mathrm{~mm}$ I.D. Analysis settings were positioned to $20 \mathrm{~min}$ at $100^{\circ} \mathrm{C}, 3 \mathrm{~min}$ at $235^{\circ} \mathrm{C}$ for column temperature, $240^{\circ} \mathrm{C}$ for injector temperature, carrier gas was helium with split ratio of 5:4. The 
running time of the sample was about $22 \mathrm{~min}$. The compounds identified their molecular weight and structure of the compounds of test materials were determined by interpretation on mass spectrum of GC-MS using the database of National Institute Standard and Technology (NIST) library.

\section{Antibacterial Assays:-}

Bacterial isolates:-

Antibiotic Susceptibility pattern of Clinical bacterial isolates from Diabetic foot ulcer was determined by disc diffusion method according to the standard guidelines prescribed by Clinical And Laboratory Standards Institute (CLSI., 2016) .Clinical isolates that exhibited Multi drug resistance were confirmed tested with VITEK 2® Compact automated system (bioMérieux, Marcy l' Etoile, France) using GN Test Kit VTK2/GP Test Kit VTK2 were included in the study. Reference type strains of Staphylococcus aureus (ATCC 29213), Escherichia coli (ATCC 25922), Pseudomonas aeruginosa (ATCC 27853), Enterococcus faecalis (ATCC 29212) obtained from CSIR-National Chemical Laboratory, Pune were also included in antibacterial study.

\section{Preliminary evaluation of antibacterial activity by disc diffusion Method:-}

Disc diffusion assay of plant extract was done by Kirby-bauer method (Bauer et al., 1966) as per CLSI guidelines (CLSI, 2016). Sterile Whatmann No.1 filter paper discs of $6 \mathrm{~mm}$ diameter of each were impregnated with $24 \mathrm{mg} / \mathrm{ml}$, $48 \mathrm{mg} / \mathrm{ml}$ of plant extract dissolved in 20\% Dimethyl Sulphoxide (DMSO) (Fischer-Scientific). Bacterial suspensions were prepared in columbia based blood agar (Himedia Laboratories) from overnight growth and the turbidity was adjusted to $0.5 \mathrm{McF}$ arland standards that gives a colony count of approximately $1 \times 10^{8} \mathrm{cfu} / \mathrm{ml}$. Using a sterile swab lawn culture of organisms was prepared on Muller Hinton Agar (Himedia Laboratories) and disc impregnated with plant extract was placed along with positive control antibiotic Vancomycin (30 $\mu \mathrm{g})$ for Gram Positive organisms, Colistin $(10 \mu \mathrm{g})$ for Gram Negative organisms and negative control (20\% DMSO). The plates were incubated at $37^{\circ} \mathrm{C}$ for 24 hours, the zone of inhibition of each well was measured and values were noted.

\section{Determination of Minimum Inhibitory Concentration (MIC) and Minimum Bactericidal Concentration (MBC):-}

MIC was determined by Macro dilution method (Wiegand et al., 2008). Plant extracts were serially diluted with Muller Hinton broth (Himedia laboratories, India) and bacterial suspensions were prepared according to manner described in disc diffusion were added to tubes containing plant extracts to obtain final desired concentrations of $0.19 \mathrm{mg} / \mathrm{ml}$ to $48 \mathrm{mg} / \mathrm{ml}$. The inoculated tubes were incubated for $37^{\circ} \mathrm{C}$ for 24 hours under aerobic conditions. Vancomycin for Gram Positive organisms and Colistin for Gram Negative organisms, in a concentration ranging from $0.125 \mu \mathrm{g} / \mathrm{ml}$ to $512 \mu \mathrm{g} / \mathrm{ml}$. Turbidity was checked after 24 hours of incubation. The lowest concentration of extract that produced no visible growth was considered as MIC.

For the determination of the MBC, tubes that produced no visible growth were gently mixed $100 \mu \mathrm{l}$ were pipette onto a sterile blood agar plates and allowed to dry. The growth control and sterility control tubes were subcultured in same manner. All the test plates checked for the colony count after overnight incubation. Concentration of the extract that inhibited the growth of bacterial colony are considered as MBC and was calculated by comparing final inoculums volume with number of colonies as rejection values as per CLSI guidelines (CLSI, 1999).

\section{Statistical Analyses:-}

All the experiments were performed in triplicates, with the results being expressed as Mean \pm SEM of three Independent experiments. The means were statistically compared using One-way ANOVA followed by post hoc Dunnett's Multiple Comparison's test by using GraphPad Prism version 5. P<0.05 was considered as statistically significant.

\section{Results and Discussion:- Phytochemical Analysis:-}

Preliminary phytochemical screening of various extracts of P. longifolia leaf summarized in Table.1, identified the presence of phytochemical constituents such as terpenoids, tannins, saponins, flavanoids, glycosides, reducing sugars in ethyl acetate and ethanol extracts of P. longifolia leaf. Parul Sharma et al (2013) also have identified the presence of flavanoids, in the ethyl acetate fractions of P.longifolia leaf collected from Cachar district of North East India. Latha et al (2013) and Padayana et al (2011) also has identified the presence of alkaloids, steroids, carbohydrates, saponins and glycosides from the bark extracts P. longifolia. 
Table 1:- Preliminary phytochemical screening of various extracts of P. longifolia leaf.

\begin{tabular}{|l|c|c|c|c|}
\hline $\begin{array}{l}\text { Phytochemical } \\
\text { constituents }\end{array}$ & Petroleum Ether & Ethyl acetate & Ethanol & Aqeuous \\
\hline Alkaloids & - & - & - & - \\
\hline Flavanoids & - & + & + & - \\
\hline Triterpenoids & - & + & + & - \\
\hline Phenolics & - & + & + & - \\
\hline Tanins & - & + & + & - \\
\hline Saponins & - & + & - & - \\
\hline Glycosides & - & + & + & - \\
\hline Steroids & - & + & + & + \\
\hline Reducing Sugars & - & - & - & - \\
\hline Protein & - & & & + \\
\hline
\end{tabular}

+ Present, - Not Present

\section{GC-MS Analysis:-}

GC-MS chromatogram of ethyl acetate and ethanol extracts of P. longifolia identified the major chemical compounds after comparing the mass spectra with NIST library. GC-MS chromatogram of ethyl extract of P. longifolia leaf (Figure.1a) identified and quantified significant phytocomponents described in Table.2. GC-MS profile of the ethanol extract of P. longifolia showed 6 major peaks (Figure.1b) also described in Table.3.

Table 2:- The phytochemical compounds present in ethyl acetate extract of P. longifolia leaf.

\begin{tabular}{|l|c|c|c|}
\hline \multicolumn{1}{|c|}{ GC-MS profile of Ethyl acetate of P. longifolia } & Retention time & Peak area & \% Peak Area \\
\hline $\begin{array}{l}\text { 1,2,4-Methenoazulene,decahydro-1,5,5,8a-tetramethyl- } \\
,[1 \mathrm{~S}-(1 \alpha, 2 \alpha, 3 \mathrm{a} \beta, 4 \alpha, 8 \mathrm{a} \beta,)]\end{array}$ & 17.57 & 1660630 & $11.44 \%$ \\
\hline $\begin{array}{l}3,7,11,15 \text {-tetramethyl-2hexadecen-1-ol (synonym: } \\
\text { Phytol) }\end{array}$ & 18.97 & 5279228 & $36.37 \%$ \\
\hline $\begin{array}{l}3,7,11,15 \text {-tetramethyl-2hexadecen-1-ol (synonym: } \\
\text { Phytol) }\end{array}$ & 19.87 & 7572568 & $52.17 \%$ \\
\hline
\end{tabular}

Previous literature has been reported Phytol for its significant antimicrobial activity against Mycobacterium tuberculosis (Rajab et al., 1998), dose dependent inhibition against S. aureus (Inoue et al., 2005). Phytol also reported for its antioxidant, antiallergic (de Fátima et al., 2006) and exhibited remarkable immunostimulant properties boosting both innate and acquired immunity (Lim et al., 2006). Palmitic acid also reported for its antibacterial and cytotoxicity activity against cancer cell lines and hepatoprotective activity (Dineshkumar \& Rajakumar., 2015). Flavones have also been reported for its anti-microbial, anti-inflammatory, anti-proliferative, antioxidant, anti-tumor, estrogenic, acetyl cholinesterase activities. (Singh et al., 2014).

Table 3:- The phytochemical compounds present in ethanol extract of P. longifolia leaf.

\begin{tabular}{|c|c|c|c|}
\hline GC-MS profile of Ethanol extract of P. longifolia & Retention time & Peak area & \% Peak Area \\
\hline $\begin{array}{l}\text { (4,4-Dimethyl-2,4,5,6-tetrahydro-1H-inden-2-yl)acetic } \\
\text { acid }\end{array}$ & 12.12 & 903744 & $11.44 \%$ \\
\hline Flavone & 14.17 & 2563280 & $13.50 \%$ \\
\hline 9,12-Hexadecadienoic acid, methyl ester & 15.98 & 1742816 & $9.18 \%$ \\
\hline $\begin{array}{l}\text { Hexadecanoic acid, ethyl ester (synonym: Ethyl } \\
\text { palmitate) }\end{array}$ & 17.78 & 3396660 & $17.89 \%$ \\
\hline $\begin{array}{l}\text { 3,7,11,15-tetramethyl-2-hexadecen-1-ol (synonym: } \\
\text { Phytol) }\end{array}$ & 18.97 & 6577686 & $34.65 \%$ \\
\hline $9,12,15$-Octadecatrienoic acid, ethyl ester & 19.50 & 3800566 & $20.01 \%$ \\
\hline
\end{tabular}



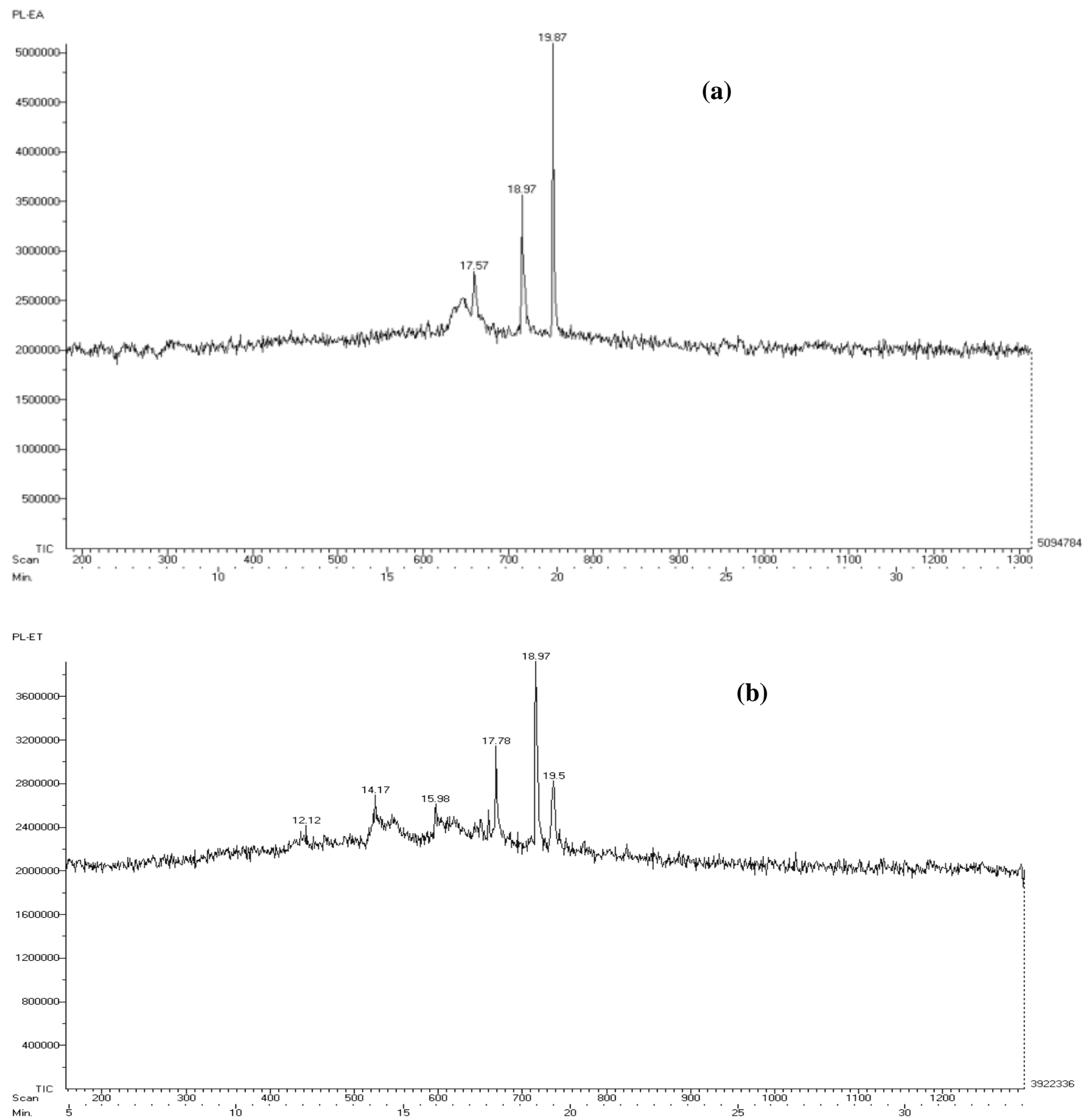

Figure 1:- GC-MS Chromatogram of (a) Ethyl acetate extract of P. longifolia (b) Ethanol extract of P. longifolia

\section{Antibacterial Activity:-}

Table.4 demonstrates the zone of inhibition of various extracts of P. longifolia leaf against standard bacterial strains and antibiotic resistant bacterial isolates from DFU by disc diffusion assay. MDR clinical isolates and ATCC bacterial strains exhibited significant activity against ethyl acetate and ethanol extracts of P. longifolia. Significant increase in the zone of inhibition was exhibited by P. aeruginosa ATCC 27853 against ethanol extract of P. longifolia. MDR- A. baumanii and MDR- E. coli was also significantly inhibited by Ethyl acetate extract of P. longifolia. All the other organisms exhibited moderate range of inhibition against ethyl acetate and ethanol extract of P. longifolia. Petroleum ether extract and aqueous extract of P. longifolia leaf were least effective against all organisms. However less potency of plant extracts can be explained as a due to the mixtures of phytochemical 
compounds in the plant extract whereas control antibiotics possess pure synthetic compound. Negative control (20\% DMSO) did not produce any zones.

Parul Sharma et al., 2013 demonstrated that ethyl acetate extract of P. longifolia leaf exhibited significant inhibition against S. aureus. Zainab et al., 2013 also has demonstrated greater activity of ethanol extracts of P. longifolia bark against Vibrio parahaemolyticus and Bacillus subtillis at a concentration of $5 \mathrm{mg} / \mathrm{ml}$. Choudhary et al., 2010 demonstrated significant inhibitory activity of acetone extract of the P. longifolia leaves against Staphylococcus sp. followed by Streptococcus sp., Klebsiella sp. and E. coli. In this study Ethyl acetate and ethanol extracts of P. longifolia leaf has exhibited significant inhibition zone against MDR bacterial strains as well as standard bacterial strains. Suresh et al., 2012 has shown highest activity of methnol and isopropanol extracts of T.chebula against MDR Diabetic foot isolates of S. aureus and P. aeruginosa . Presence of biological active compounds (flavanoids, tannins, saponins, phenolics) and compounds identified through GC-MS analysis account for higher antibacterial activity against wild and standard gram negative and gram positive organisms.

Based on MIC/MBC ranges summarized in Table.5, ethyl acetate and ethanol extracts of P. longifolia leaf were only significant against MDR clinical isolates from DFU as well as against standard bacterial strains. The minimum inhibitory concentration (MIC) of Ethyl acetate extract and ethanol extracts of P. longifolia leaf against all bacterial strains ranged between $12 \mathrm{mg} / \mathrm{ml}$ to $48 \mathrm{mg} / \mathrm{ml}$.

Table 4:- Mean zone of inhibition $(\mathrm{mm})^{\text {a }}$ of different crude leaf extracts of P. longifolia by disc diffusion ${ }^{\mathbf{b}}$ assay

\begin{tabular}{|c|c|c|c|c|c|c|c|c|c|c|}
\hline \multirow{2}{*}{$\begin{array}{l}\text { Bacterial } \\
\text { Strains }\end{array}$} & \multicolumn{2}{|c|}{ Petroleum Ether } & \multicolumn{2}{|c|}{ Ethyl Acetate } & \multicolumn{2}{|c|}{ Ethanol } & \multicolumn{2}{|c|}{ Aqueous } & \multirow[t]{2}{*}{ Control $^{\mathrm{c}}$} & \multirow[t]{2}{*}{ Antibiotic $^{d}$} \\
\hline & $4 \mathrm{mg} / \mathrm{ml}$ & $\begin{array}{c}\text { 48mg/ } \\
\mathrm{ml}\end{array}$ & $\begin{array}{c}24 \mathrm{mg} / \\
\mathrm{ml}\end{array}$ & $\begin{array}{c}48 \mathrm{mg} / \\
\mathrm{ml}\end{array}$ & $\begin{array}{c}24 \mathrm{mg} / \\
\mathrm{ml}\end{array}$ & $\begin{array}{c}48 \mathrm{mg} / \\
\mathrm{ml}\end{array}$ & $\begin{array}{c}24 \mathrm{mg} / \\
\mathrm{ml}\end{array}$ & $\begin{array}{c}48 m g \\
/ \mathrm{ml}\end{array}$ & & \\
\hline $\begin{array}{l}\text { S.aureus } \\
\text { ATCC } \\
29213 \\
\end{array}$ & $\begin{array}{l}9.33 \pm \\
0.33\end{array}$ & $\begin{array}{l}11.67 \pm \\
1.20\end{array}$ & $\begin{array}{l}16.33 \pm \\
0.67\end{array}$ & $\begin{array}{l}19.33 \pm \\
0.67\end{array}$ & $\begin{array}{l}12.67 \pm \\
0.33\end{array}$ & $\begin{array}{l}15.00 \pm \\
0.58\end{array}$ & $\begin{array}{l}6.00 \pm \\
0.00\end{array}$ & $\begin{array}{l}6.00 \pm \\
0.00\end{array}$ & - & $\begin{array}{l}19.67 \pm \\
0.88\end{array}$ \\
\hline $\begin{array}{l}\text { P.aerugin } \\
\text { osa } \\
\text { ATCC } \\
27853\end{array}$ & $\begin{array}{l}8.00 \pm \\
0.00\end{array}$ & $\begin{array}{l}9.00 \pm \\
0.58\end{array}$ & $\begin{array}{l}11.00 \pm \\
0.58\end{array}$ & $\begin{array}{l}12.00 \pm \\
0.58\end{array}$ & $\begin{array}{l}24.33 \pm \\
0.33^{* * * *}\end{array}$ & $\begin{array}{l}25.33 \pm \\
0.33^{* * * *}\end{array}$ & $\begin{array}{l}6.00 \pm \\
0.00\end{array}$ & $\begin{array}{l}6.00 \pm \\
0.00\end{array}$ & - & $\begin{array}{l}13.33 \pm \\
0.88\end{array}$ \\
\hline $\begin{array}{l}\text { E.faecalis } \\
\text { ATCC } \\
29212 \\
\end{array}$ & $\begin{array}{l}6.00 \pm \\
0.00\end{array}$ & $\begin{array}{l}6.00 \pm \\
0.00\end{array}$ & $\begin{array}{l}11.00 \pm \\
0.00\end{array}$ & $\begin{array}{l}14.00 \pm \\
1.00\end{array}$ & $\begin{array}{l}10.33 \pm \\
0.33\end{array}$ & $\begin{array}{l}14.00 \pm \\
0.58\end{array}$ & $\begin{array}{l}6.00 \pm \\
0.00\end{array}$ & $\begin{array}{l}9.00 \pm \\
0.00\end{array}$ & - & $\begin{array}{l}18.33 \pm \\
0.88\end{array}$ \\
\hline $\begin{array}{l}\text { E.coli } \\
\text { ATCC } \\
25922 \\
\end{array}$ & $\begin{array}{l}9.33 \pm \\
0.33\end{array}$ & $\begin{array}{l}10.33 \pm \\
0.33\end{array}$ & $\begin{array}{l}11.67 \pm \\
0.67\end{array}$ & $\begin{array}{l}14.00 \pm \\
0.58\end{array}$ & $\begin{array}{l}11.67 \pm \\
0.88\end{array}$ & $\begin{array}{l}12.33 \pm \\
0.88\end{array}$ & $\begin{array}{l}6.00 \pm \\
0.00\end{array}$ & $\begin{array}{l}6.00 \pm \\
0.00\end{array}$ & - & $\begin{array}{l}16.00 \pm \\
1.16\end{array}$ \\
\hline $\begin{array}{l}\text { MDR- } \\
\text { MRSA }\end{array}$ & $\begin{array}{l}6.00 \pm \\
0.00\end{array}$ & $\begin{array}{l}6.00 \pm \\
0.00\end{array}$ & $\begin{array}{l}6.33 \pm \\
0.33 \\
\end{array}$ & $\begin{array}{l}11.00 \pm \\
0.58\end{array}$ & $\begin{array}{l}6.00 \pm \\
0.00 \\
\end{array}$ & $\begin{array}{l}6.00 \pm \\
0.00\end{array}$ & $\begin{array}{l}6.00 \pm \\
0.00\end{array}$ & $\begin{array}{l}6.00 \pm \\
0.00\end{array}$ & - & $\begin{array}{l}18.67 \pm \\
0.67 \\
\end{array}$ \\
\hline $\begin{array}{l}\text { MDR- } \\
\text { P.aerugin } \\
\text { osa }\end{array}$ & $\begin{array}{l}6.00 \pm \\
0.00\end{array}$ & $\begin{array}{l}9.00 \pm \\
0.58\end{array}$ & $\begin{array}{l}12.00 \pm \\
0.58\end{array}$ & $\begin{array}{l}14.33 \pm \\
0.33\end{array}$ & $\begin{array}{l}11.00 \pm \\
0.58\end{array}$ & $\begin{array}{l}14.67 \pm \\
0.67\end{array}$ & $\begin{array}{l}6.00 \pm \\
0.00\end{array}$ & $\begin{array}{l}6.00 \pm \\
0.00\end{array}$ & - & $\begin{array}{l}16.00 \pm \\
0.00\end{array}$ \\
\hline $\begin{array}{l}\text { MDR- } \\
\text { A.bauman } \\
\text { ii }\end{array}$ & $\begin{array}{l}8.67 \pm \\
1.33\end{array}$ & $\begin{array}{l}8.67 \pm \\
1.33\end{array}$ & $\begin{array}{l}16.33 \pm \\
1.20^{*}\end{array}$ & $\begin{array}{l}18.00 \pm \\
1.53^{* * * *}\end{array}$ & $\begin{array}{l}13.00 \pm \\
0.58\end{array}$ & $\begin{array}{l}13.67 \pm \\
0.33\end{array}$ & $\begin{array}{l}6.00 \pm \\
0.00\end{array}$ & $\begin{array}{l}9.00 \pm \\
0.00\end{array}$ & - & $\begin{array}{l}12.00 \pm \\
1.16\end{array}$ \\
\hline $\begin{array}{l}\text { MDR- } \\
\text { E.coli }\end{array}$ & $\begin{array}{l}6.00 \pm 0 . \\
00\end{array}$ & $\begin{array}{l}9.67 \pm \\
0.33\end{array}$ & $\begin{array}{l}12.00 \pm \\
0.58\end{array}$ & $\begin{array}{l}16.0 \pm \\
0.58^{*}\end{array}$ & $\begin{array}{l}11.00 \pm \\
0.58\end{array}$ & $\begin{array}{l}12.33 \pm \\
1.20\end{array}$ & $\begin{array}{l}6.00 \pm \\
0.00\end{array}$ & $\begin{array}{l}9.00 \pm \\
0.00\end{array}$ & - & $\begin{array}{l}13.00 \pm \\
0.58\end{array}$ \\
\hline
\end{tabular}

adiameter zone of inhibition $(\mathrm{mm})$ including the disk diameter of $6 \mathrm{~mm} ;{ }^{b}$ mean of three assays \pm standard error mean;

${ }^{\mathrm{c}}$ negative control $20 \%$ DMSO; ${ }^{\mathrm{d}}$ antibiotic positive control

Vancomycin $30 \mu \mathrm{g} / \mathrm{disc}$ for gram positive and Colistin $10 \mu \mathrm{g} / \mathrm{disc}$ for gram negative bacteria. ${ }^{* * * *} \mathrm{P}<0.001,{ }^{* * *} \mathrm{P}<0.01$,

${ }^{*} \mathrm{P}<0.05 . \mathrm{P}<0.05$ was considered as statistically significant. 
The MBC values were 2-4 folds higher than MIC values for the extract. P. aeruginosa ATCC 27853 against ethanol extracts of P. longifolia, E. coli ATCC 25922 and MDR clinical isolate A. baumanii showed lowest value of MIC/MBC (MBC-MIC ratio of 2) against ethyl acetate extracts of P. longifolia leaf indicating its significant bactericidal properties. Zhang et al., (2015) also has demonstrated bactericidal property of Mentha arvensis ethanol extract against MDR A. baumanii at a MIC of $23.5 \mu \mathrm{g} / \mathrm{ml}$. Ethanol extracts of P. longifolia leaf exhibited significant MIC values against all clinical MDR bacterial isolates and standard bacterial strains except E. faecalis ATCC 29212. Petroleum ether and aqueous extracts of P. longifolia leaf were least effective based on highest value of MIC/MBC results. P. aeruginosa, Enterobacteriaceae, S. aureus and Enterococci, acted to varying extents about $0.13-8 \mathrm{mg} / \mathrm{ml}$ against the methanol extracts of E. abyssinica, T. spinosa, X. caffra, and the stem bark of A. indica (Fabry., 1998). Studies by Carrington et al (2012) on methanol and acetone extracts Barbadian Medicinal Plants against the bacteria S. aureus ATCC 25923, P. aeruginosa ATCC 27853, and clincal strain E. feacalis from diabetic wounds yielded no antimicrobial activity, whereas in the present study ethyl acetate and ethanol extracts of P. longifolia where moderately effective against clinical bacterial strains isolated from DFU as well as against ATCC bacterial strains.

Table 5:- MIC and MBC values of Crude leaf extracts of P. longifolia.

\begin{tabular}{|c|c|c|c|c|c|c|c|c|c|}
\hline \multirow[t]{2}{*}{ Bacterial Strains } & \multicolumn{2}{|c|}{$\begin{array}{c}\text { Petroleum } \\
\text { Ether }(\mathrm{mg} / \mathrm{ml})\end{array}$} & \multicolumn{2}{|c|}{$\begin{array}{c}\text { Ethyl Acetate } \\
(\mathrm{mg} / \mathrm{ml})\end{array}$} & \multicolumn{2}{|c|}{$\begin{array}{l}\text { Ethanol } \\
(\mathrm{mg} / \mathrm{ml})\end{array}$} & \multicolumn{2}{|c|}{$\begin{array}{c}\text { Aqueous } \\
(\mathrm{mg} / \mathrm{ml})\end{array}$} & \multirow[t]{2}{*}{$\begin{array}{c}\text { Control } \\
\text { Antibiotic* }\end{array}$} \\
\hline & MIC & MBC & MIC & MBC & MIC & MBC & MIC & MBC & \\
\hline S. aureus ATCC 29213 & $>48$ & $>48$ & 24 & 48 & 24 & 48 & $>48$ & $>48$ & 0.5 \\
\hline $\begin{array}{l}\text { P. aeruginosa ATCC } \\
27853\end{array}$ & $>48$ & $>48$ & 12 & 48 & 12 & 24 & $>48$ & $>48$ & 1 \\
\hline E. faecalis ATCC 29212 & $>48$ & $>48$ & 24 & $>48$ & 48 & $>48$ & $>48$ & $>48$ & 1 \\
\hline E. coli ATCC 25922 & $>48$ & $>48$ & 12 & 24 & 48 & $>48$ & $>48$ & $>48$ & 1 \\
\hline MDR-MRSA & $>48$ & $>48$ & 12 & 48 & 12 & $>48$ & $>48$ & $>48$ & 1 \\
\hline MDR-P. aeruginosa & $>48$ & $>48$ & 12 & 48 & 24 & $>48$ & $>48$ & $>48$ & 0.5 \\
\hline MDR-A. baumanii & $>48$ & $>48$ & 12 & 24 & 24 & 48 & $>48$ & $>48$ & 0.5 \\
\hline MDR-E. coli & $>48$ & $>48$ & 12 & 48 & 24 & 48 & $>48$ & $>48$ & 0.5 \\
\hline
\end{tabular}

*Control Antibiotic, Vancomycin for gram positive and Colistin for gram negative bacteria

Our present study identified the presence of various phytochemical constituents in ethyl acetate and ethanol extracts of P. longifolia leaf and also major chemical compounds were analyzed through GC-MS. Antibacterial studies of plant extracts against MDR bacterial isolates from DFU and ATCC bacterial strains displayed moderate range of bactericidal properties. However, further studies should be done on isolation and identification of the pharmacologically active compounds to understand the exact molecular mechanism of action. The purified constituents contributing to antibacterial activity would be then used for novel cost-effective drug leads.

\section{Acknowledgments:-}

We would like to acknowledge the financial support from DST- Inspire fellowship scheme under the guidance Dr. G. Shanthi., MD., Ph.D. The authors wish to thank Professor \& Head, Department of Pharmacy, Annamalai University for providing necessary facilities to carry out this work. Authors cordially thank Sophisticated Analytical Instrument Facility, IIT Chennai for recording GC-MS Profile

\section{References:-}

1. A.W.Bauer, W.M.M.Kirby, J.C.Sherris, M.Turk (1966) Antibiotic susceptibility testing by standard single disk method. Am J Clin Pathol 45:493-496.

2. Abdulrazak A, Ibrahim Bitar Z, Ayesh Al-Shamali A, Ahmed Mobasher L (2004) Bacteriological study of diabetic foot infections. J Diabetes Complications 19:138-141.

3. Akunyili, D.N., Houghton, P.J., Raman, A. (1991) Antimicrobial activities of the stembark of Kigelia pinnata. J Ethnopharmacol 35:173-177.

4. Alavi, A., Sibbald, R.G., Mayer, D., et al (2014) Diabetic foot ulcers: Part II. Management. J Am Acad Dermatol 70:21.e1-21.e24.

5. Asha K, Latha KP, Vagdevi HM (2013) Phytochemical Screening And Analgesic Activity Of Bark Extracts. Univers J Pharm 2:107-110. 
6. Baveja CP, Gumma VN, Jain M, Jha H (2010) Foot ulcer caused by multidrug-resistant Mycobacterium tuberculosis in a diabetic patient. J Med Microbiol 59:1247-1249.

7. Caballero, E., Frykberg, R.G. (1998) Diabetic foot infections. J Foot Ankle Surg 37:248-255.

8. Carrington S, Cohall DH, Lindo JF (2012) The Antimicrobial Screening of a Barbadian Medicinal Plant with Indications for for use in the treatment of Diabetic Wound Infections. West Indian Med J 61:861-864.

9. Chander, M.P., Kartick C, Vijayachari P (2015) Herbal medicine \& healthcare practices among Nicobarese of Nancowry group of Islands - An indigenous tribe of Andaman \& Nicobar Islands. Indian J Med Res 141:720744.

10. Charles, P.G.P., Uckay, I., Kressmann, B., et al (2015) The role of anaerobes in diabetic foot infections. Anaerobe 34:8-13.

11. Chin Y-W, Balunas MJ, Chai HB, Kinghorn AD (2006) Drug discovery from natural sources. AAPS J 8:E23953.

12. Choudhury S, Choudhury MD, Sharma GD, Paul SB (2010) Antibacterial Activity of Crude Leaf Extracts of Pajanelia longifolia (Willd .) K . Schuman. Assam Univ J Sci Technol 5:53-57.

13. Clinical and labortaory Standard Institute (CLSI) (2016) Clinical and Labortaory Standard Institute (CLSI): Performance Standards for Antimicrobial Susceptibility Testing: Twenty-sixth Informational Supplement (M100-S25) Wayne PA.

14. Clinical and labortaory Standard Institute CLSI (1999) M26-A: Methods for Determining Bactericidal Activity of Antimicrobial Agents; Approved Guideline. 1-29.

15. Cunha, B.A. (2000) Antibiotic selection for diabetic foot infections: A review. J Foot Ankle Surg 39:253-257.

16. De Fátima A, Modolo L V, Conegero LS, et al (2006) Styryl lactones and their derivatives: biological activities, mechanisms of action and potential leads for drug design. Curr Med Chem 13:3371-3384.

17. Dineshkumar G, Rajakumar R (2015) GC-MS Evaluation Of Bioactive Molecules From The Methanolic Leaf Extract Of Azadirachta Indica ( A . Juss ). Asian J Pharm Sci Technol 5:64-69.

18. Djahmi, N., Messad, N., Nedjai, S., et al (2013) Molecular epidemiology of staphylococcus aureus strains isolated from inpatients with infected diabetic foot ulcers in an Algerian University Hospital. Clin Microbiol Infect 19:E398-E404.

19. Fabry W, Okemo PO, Ansorg R (1998) Antibacterial activity of East African medicinal plants. J Ethnopharmacol 60:79-84.

20. Gadepalli R, Dhawan B, Sreenivas V, et al (2006) A clinico-microbiological study of diabetic foot ulcers in an Indian tertiary care hospital. Diabetes Care 29:1727-1732.

21. Goldstein EJC, Citron DM, Merriam CV, Tyrrell KL (2013) Comparative in vitro activity of ceftaroline, ceftaroline-avibactam, and other antimicrobial agents against aerobic and anaerobic bacteria cultured from infected diabetic foot wounds. Diagn Microbiol Infect Dis 76:347-351.

22. Harborne JB (1998) Phytochemical Methods: A guide to Modern Techniques of Plant Analysis.

23. Inoue Y, Hada T, Shiraishi A, et al (2005) Biphasic effects of geranylgeraniol, teprenone, and phytol on the growth of Staphylococcus aureus. Antimicrob Agents Chemother 49:1770-1774.

24. Kernan MR, Amarquaye A, Chen JL, et al (1998) Antiviral phenylpropanoid glycosides from the medicinal plant Markhamia lutea. J Nat Prod 61:564-570.

25. Kong, DeXin., Li, Xue Juan., Zhang, Hong Yu. (2009) Where is the hope for drug discovery? Let history tell the future. Drug Discov Today 14:115-119.

26. Kumar Anil, N., P, M, Salim., Balakrishnan, V., Sivan, V V (2007) Medicinal Plants Known from Wayanad,A checklist with local Names,Botanical Names,Habit and Habitat.

27. Lim S Y, Meyer M, Kjonaas R a, Ghosh SK (2006) Phytol-based novel adjuvants in vaccine formulation: 1. assessment of safety and efficacy during stimulation of humoral and cell-mediated immune responses. $\mathrm{J}$ Immune Based Ther Vaccines 4:1-10.

28. Longanga Otshudi A, Vercruysse A, Foriers A (2000) Contribution to the ethnobotanical, phytochemical and pharmacological studies of traditionally used medicinal plants in the treatment of dysentery and diarrhoea in Lomela area, Democratic Republic of Congo (DRC). J Ethnopharmacol 71:411-423.

29. Mendes JJ, Marques-Costa a., Vilela C, et al (2012) Clinical and bacteriological survey of diabetic foot infections in Lisbon. Diabetes Res Clin Pract 95:153-161.

30. Murali TS, Kavitha S, Spoorthi J, et al (2014) Characteristics of microbial drug resistance and its correlates in chronic diabetic foot ulcer infections. J Med Microbiol 63:1377-1385.

31. Onegi, B., Kraft, C., Köhler, I., et al (2002) Antiplasmodial activity of naphthoquinones and one anthraquinone from Stereospermum kunthianum. Phytochemistry 60:39-44. 
32. Padyana S, Zainab A, Ashalatha M, Acharya S (2011) Antioxidant and antibacterial properties of Pajanelia longifolia (willd .) K. Schum. Ann Biol Rsearch 2:11-18.

33. Patwardhan, B., Vaidya, A.D.B., Chorghade, M. (2004) Ayurveda and natural products drug discovery. Curr Sci 86:789-799.

34. Rajab MS, Cantrell CL, Franzblau, S. G. \&, Fischer NH (1998) Antimycobacterial activity of ( E ) -phytol and derivatives : a preliminary structure- activity study. Planta Med 64:2-4.

35. Rogers LC, Frykberg RG, Armstrong DG, et al (2011) The Charcot foot in diabetes. Diabetes Care 34:21232129.

36. Roy Choudhury P, Dutta Choudhury M, Ningthoujam SS, et al (2015) Ethnomedicinal plants used by traditional healers of North Tripura district, Tripura, North East India. J Ethnopharmacol 166:135-48.

37. Sapico, F.L., Canawati, H.N., Witte, J.L., et al (1980) Quantitative aerobic and anaerobic bacteriology of infected diabetic feet. J Clin Microbiol 12:413-420.

38. Sharma P, Mazumder, Sandipan., Choudhury S (2013) Preliminary phytochemical screening and antibacterial activity of (Acalypha indica L ). Int J Res Biol Sci 3:161-164.

39. Singh M, Kaur M, Silakari O (2014) Flavones: An important scaffold for medicinal chemistry. Eur J Med Chem 84:206-239.

40. Srivastava D, Harris RC, Waters CM (2011) Integration of cyclic di-GMP and quorum sensing in the control of vpsT and aphA in Vibrio cholerae. J Bacteriol 193:6331-6341.

41. Suresh A, Muthu G, Suresh GS, et al (2012) Screening of Antibacterial Properties of Indian Medicinal Plants against Multi Drug Resistant Diabetic Foot Ulcer Isolates. Int J Phytopharm 3:139-146.

42. Sussman, K.E., Reiberb, G., Albert, F. (1992) The diabetic foot problem - a failed system of health care? Diabetes Res Clin Pract 17:1-8.

43. Wiegand I, Hilpert K, Hancock REW (2008) Agar and broth dilution methods to determine the minimal inhibitory concentration (MIC) of antimicrobial substances. Nat Protoc 3:163-175.

44. Zainab A, Bhat Rama P, Acharya S, et al (2013) Studies on Antioxidant and Antimicrobial Activities of Pajanelia longifolia(Wild.) Schumann. J Res Obes 2013:1-9.

45. Zhang L, Xu S, Liang W, et al (2015) Antibacterial Activity and Mode of Action of Mentha arvensis Ethanol Extract against Multidrug-Resistant Acinetobacter baumannii. Trop J Pharm Res 14:2099-2106. 